\title{
EZÜSTTÁLKA EGY KORA AVAR KORI SÍRBAN BONYHÁDRÓL
}

\author{
K. TÓTH GÁBOR*
}

\begin{abstract}
Jelen tanulmány a Bonyhádtól (Tolna megye) északra fekvő Szöcske-szántók dülóben talált kora avar korra keltezhetö, viszonylag gazdag melléklettel bíró sírnak és mellékleteinek a leírását tartalmazza. A temetkezés idejét a sírból előkerült leletek alapján a kora avar korra, a 6. század végére 7. század elejére lehet tenni. A leletegyüttesben a tarsolyzáróként szolgáló egykori bizánci füstölöhöz tartozó elem és az ezüstcsésze a Balkán bizánci térségéböl, egy kirabolt templom felszereléséböl származhat és egy olyan személy leletegyütteséhez tartozhatott, aki maga is részt vett az avarok balkáni hadjárataiban, vagy ilyen személyekkel kapcsolatban állt.
\end{abstract}

Kulcsszavak: avar, sír, késő antik toreutika, ezüsttál, bizánci kis tárgy, tegez, nyílhegyek

Presented and discussed here is a burial with a relatively rich array of grave goods dating from the Early Avar period found in an area known as Szöcske-szántók lying north of Bonyhád (County Tolna). On the testimony of the finds recovered from the burial, the grave can be assigned to the Early Avar period, to the late 6th-early 7th century. An element taken from a Byzantine censer that was repurposed to serve as a purse clasp and the silver bowl obviously originated from a looted church in Byzantium's Balkanic province and were the possessions of a person who had participated in the Avars' Balkanic campaigns or who had contact with these individuals.

Keywords: Avar, burial, late antique toreutics, silver bowl, Byzantine small finds, quiver, arrowheads

2018 tavaszán a Wosinsky Mór Megyei Múzeum régészei (Czövek Attila, K. Tóth Gábor), múzeumbarát fémkeresősök (Bulla László, Vincze Péter) bejelentései alapján terepszemlét tartottak a Bonyhádtól északra fekvó Szöcske-szántók dúlőben. A dúlő a Majosi-árok és az Aparhanti patak összefolyásánál található, egy Ny-K-i irányú, erősen a térszín fölé emelkedő félszigeten, 110-130 méteres tengerszint feletti magasságon (1. kép). A lelőhelyen több korszak anyaga is fellelhetó a római kortól kezdve az újkorig. IV. századi római érmék, avar kori szíjvég, III. Béla rézből vert tálkapénze, török kori akcsék, III. Ferdinánd dénárja és III. Zsigmond lengyel király garasa került be a múzeumba, múszeres felderítés során. A dúlőben található egyik mezsgyeárok aljából egy 6 . század végére - 7 . század elejére keltezhetó sír került elő.

\footnotetext{
* Kézirat beérkezett: 2020. március 3. Kézirat elfogadva: 2020 június 27.

* K. Tóth Gábor: Wosinsky Mór Megyei Múzeum, 7100 Szekszárd, Szent István tér 26., e-mail: k.toht.gabor@wmmm.hu
}

\section{A sír leírása}

Férfi, adultus, ${ }^{1}$ a váz nyújtott háton fekvő, deréktól lefelé bolygatott. Lekerekített téglalap alaprajzú sír, a két vége lemélyített (2-3. kép). Sírhossz: $206 \mathrm{~cm}$; sírszélesség: $58 \mathrm{~cm}$; sírmélység: $50 \mathrm{~cm}$. Tájolás: NyDNy-KEK, 84-264․

A koponyától balra ezüsttálka (1. mell), az álkapocstól jobbra bronzveret töredéke (2. mell.), az álkapocstól jobbra csontfésú töredéke (3. mell.), a bal felkartól balra, $30 \mathrm{~cm}$-rel magasabban, $3 \mathrm{db}$ nyílhegy (4. 1-3. mell.), a bal felkartól balra, $30 \mathrm{~cm}$-rel magasabban, $8 \mathrm{db}$ tegezveret és 1 tegezzáró csat (5.1-2. mell.), a bal könyök belső oldalán bronz szíjvég töredéke (6. mell.), a bal csípőlapát felett tegezveret töredéke (7. mell.), a jobb medencelapát felett vascsat (8. mell.), a jobb medencelapáton vascsat (9. mell.), a jobb meden-

1 Az elhunyt korának és nemének meghatározását Mende Balázs Gusztávnak ezúton köszönöm. 


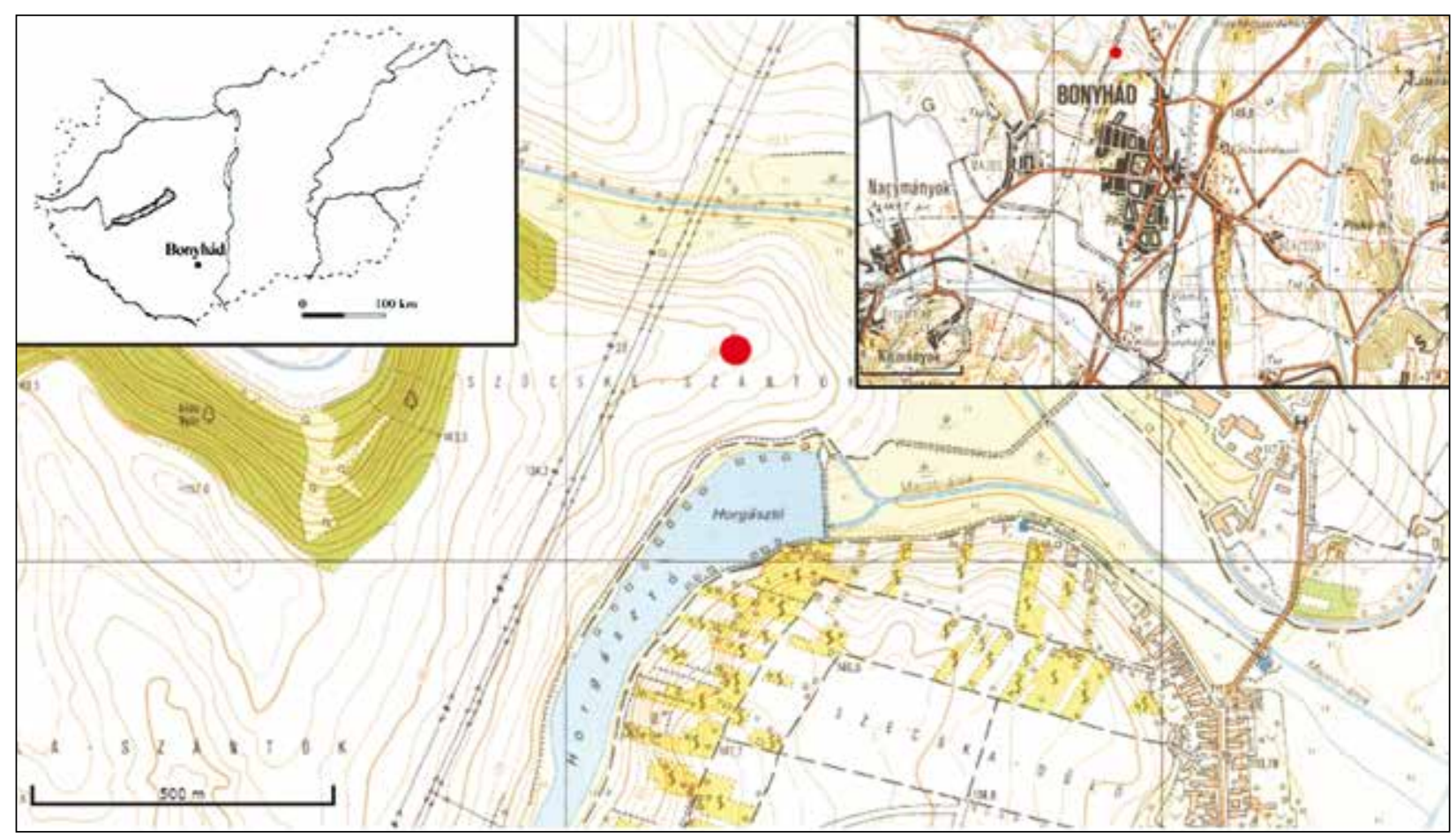

1. kép. A Bonyhád-Szöcske-szántók lelőhely helyzete

Fig. 1. Location of the Bonyhád-Szöcske-szántók site

celapát alsó felén tarsolyzáró (10. mell.), a jobb medencelapát alatt egyben szíjvég, bronztárgy, csiholó vas-bronzlemez, kovakő (11. 1-4. mell.), a jobb medencelapát alatt vaskés töredéke (12. mell.), a jobb medencelapát alatt vascsiholó töredéke (13. mell.), a combcsontok között tegezveret rögzítőszegecse (14. mell.), a bal medencelapát külső oldalánál lemezes nagyszíjvég (15. mell.), az északi sírfal oldalában a sír alsó harmadában római kori érme (16. mell.). Szórványok a váz felszedését követően kerültek elő. A sírgödör középső részén, gyöngy (17. 1. mell.) és egy tegezveret (17. 2. mell.).

\section{Leletek}

1. Ezüsttál (4-5. kép). ${ }^{2}$ A tál félgömb alakú, vékony, milliméternél is keskenyebbre kikalapált ezüstlemezból készült. A perem alatt két sávban trébelt sordísz fut körbe. A felső sávban félgömb vagy tojás alakú minta látható. A félgömböket egymásra csúsztatták, egymást negyedrészben kitakarják, így valójában félhold alakúnak látszanak. Ezeket a mintákat a belső oldalról kalapálták ki, a tál külső oldalán domborodnak. Az alsó sávban enyhén

2 Csiszér Antalnak a tárgyrajzok, Retkes Tamásnak a fényképek elkészítését, Vicze Lászlónak a táblák szerkesztését ezúton köszönöm. rombusz alakú mintasor látható, amely szinte összeér a felső sávban található mintákkal. Ezeket az elemeket a felső sorral ellentétben kívülről kalapálták be, a tál belső oldalán domborodnak. Súly: 37,268 g; Átm.: 12,6 cm; Magasság 5,2 cm.

2. Bronz verettöredék (6. kép 27). Lapos „U” alakú rögzítőkapocs, amorf alakú bronztöredékkel. H.: 1,9 cm. Talán a tegezveretek közé sorolható, mely állatjárás során került el az eredeti helyéről.

3. Csontfésú töredék (6. kép 1). Töredékes csontlapocska a fésú fogainak indításával, vasszegeccsel és egy kis bronz pálcataggal. H.: $2 \mathrm{~cm}$. Csak a vasszegecs körüli csontlap maradt meg.

4. Nyílhegyek, 3 db (6. kép 16-17, 30). A sírgödör É-i oldalánál a váll magasságában, a sírgödör aljánál $30 \mathrm{~cm}$ rel magasabban $3 \mathrm{db}$ összekorrodálódott nyílhegy került elő.

4.1. Nyílhegy. Háromélú, levél alakú, nyéltüskés, íves pengéjú/vágóélú nyílcsúcs. H.: 12,2 cm (a levél h.: 6,1 cm; köpü h.: 6,1 cm); legnagyobb szélessége (az alsó harmadában): $2,2 \mathrm{~cm}$.

4.2. Nyílhegy. Háromélú, nyéltüskés, tompaszögú nyílhegy. A vágóél és a váll tompaszöget zár be. A váll vonala csaknem párhuzamos a nyílcsúcs tengelyével. H.: $8,7 \mathrm{~cm}$ (a levél h.: $6 \mathrm{~cm}$; köpü h.: 2,7 cm); legnagyobb szélessége (a felsó negyedben): 2,6 cm.

4.3. Nyílhegy. Lapos, kétélú, levél alakú, erősen hiányos nyílhegy. A vágóél hegyesszögú, a váll íves. H.: 5,8 cm; legnagyobb szélessége (az alsó harmadban): $4,2 \mathrm{~cm}$. 


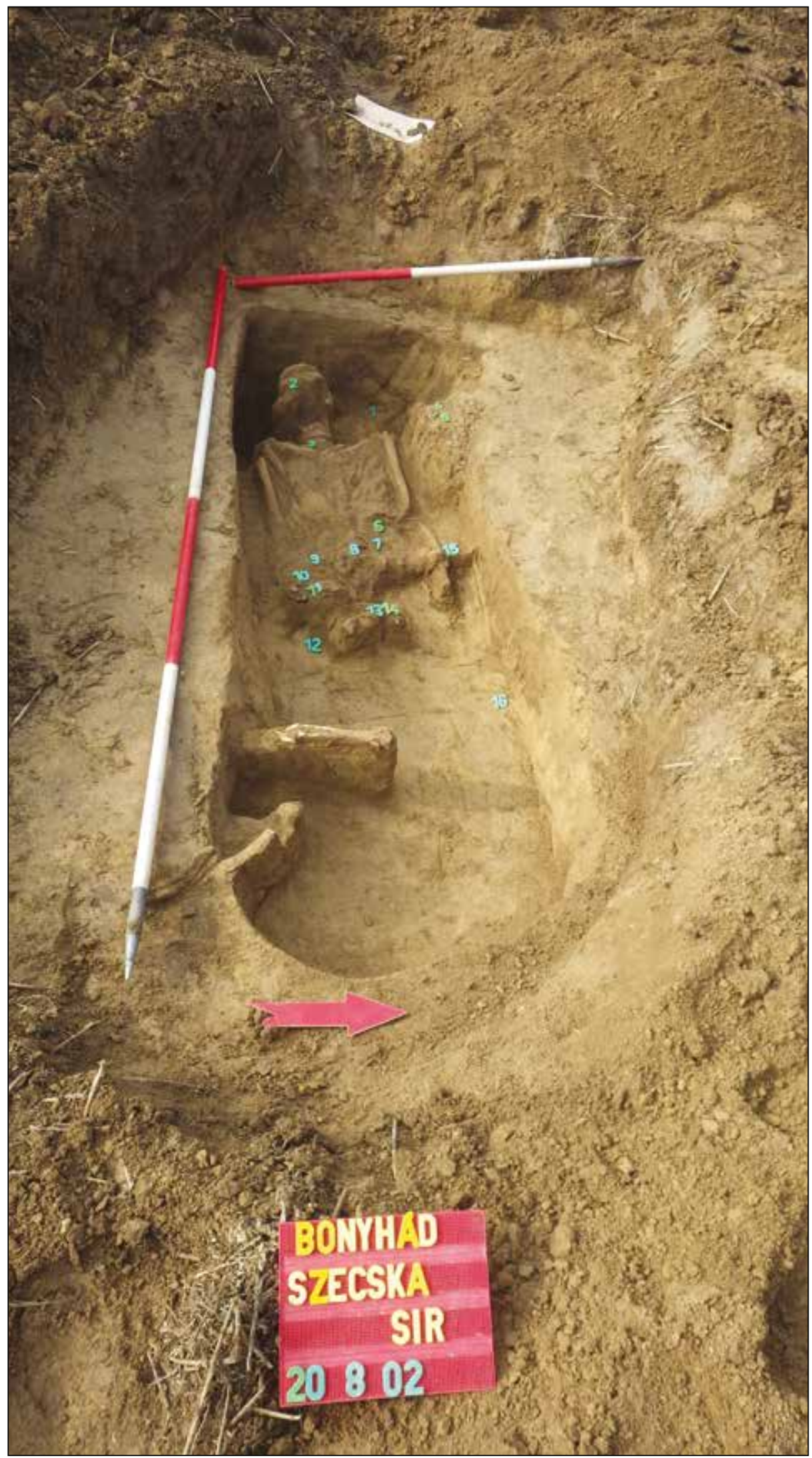

2. kép. Bonyhád-Szöcske-szántók. A leletmentés során kibontott sír. (Fotó: K. Tóth Gábor)

Fig. 2. Bonyhád-Szöcske-szántók. The grave unearthed during the rescue excavation. (Photo: Gábor K. Tóth) 


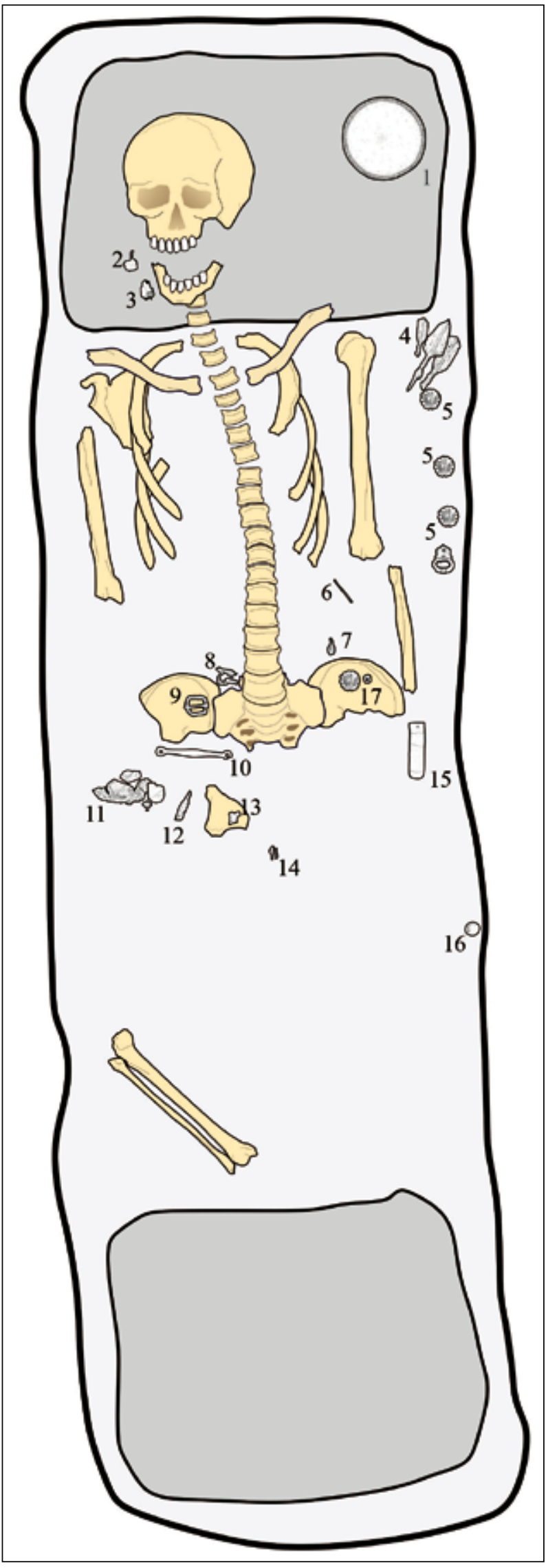

5. Tegezveretek, tegezzáró csat (6. kép 18-25, 28).

5.1. Tegezveret $(8 \mathrm{db})$, bronzlemezből préselt, gömbsordíszes, közepén félgömbbel díszített, tegezveret, „U” alakú rögzítőszegecsekkel. Átm.: $2 \mathrm{~cm}$.

5.2. Tegezzáró csat. Egytagú, címer/pajzs alakú csat, rövid csattesttel, széles, ovális formájú csatfejjel, két rögzítőszegeccsel. H.: 2,6 cm; legnagyobb sz.: 1,9 cm.

6. Bronz szíjvég (6. kép 5). Bronzból készült szíjvég oldalmerevító pálcatagja. A lemezek hiányoznak. H.: $4,2 \mathrm{~cm}$.

7. Tegezveret (6. kép 6). Bronzlemezből préselt, gömbsordíszes, közepén félgömbbel díszített tegezveret töredék, „U” alakú rögzítőszegeccsel.

8. Vascsat (6. kép 2). Lant alakú vascsat töredéke. H.: $3,6 \mathrm{~cm}$.

9. Vascsat (6. kép 3). Téglalap alakú vascsat. H.: 3,7 cm; sZ.: $2,8 \mathrm{~cm}$.

10. Tarsolyzáró (6. kép 9). Sárgarézből öntött, elnyúlt, piskóta alakú, középen kiszélesedő, tarsolyzáró, végei körívesek és átlyukasztottak. H.: 13,3 cm; legnagyobb sz.: $1,3 \mathrm{~cm}$.

11. Szíjvég, bronztárgy, csiholó vas-bronzlemez és kovakő

11.1. Szijvég. Lemezes, széles bronz szíjvég, felső végét pánt fogja körbe. H.: 3,1 cm; sz.: 2,4 cm (6. kép 12).

11.2. Bronztárgy. Lapított gömb alakú bronztárgy, közepén letört pálcataggal. Valószínúleg egy római kori fibula letört gombja lehet. Átm.: 1,5 cm (6. kép 13).

11.3. Csiholó vas. Enyhén ívelt hátú, a két vége elkeskenyedik és visszahajlik. A hát belső íve csúcsos. H.: $10 \mathrm{~cm}$; legnagyobb sz.: 3,6 cm. Bronzlemez. Lapos, palástos bronzlemez teljesen összekorrodálódva a csiholó vassal. H.: 2,2 cm; sz.: $2 \mathrm{~cm}$. A bronzlemez egy bronz pálcatagot vesz körül (6. kép 14-15).

11.4. Kovakő $(2 \mathrm{db})$. Szürke színú ötszögletú, limnokvarcit, vasrozsda foltokkal. H.: $3,7 \mathrm{~cm}$; sz.: $2 \mathrm{~cm}$. Sárga színú, amorf alakú limnokvarcit. H.: 2,6 cm; sz.: 1,8 cm.

12. Vaskés (6. kép 29). Felső nyélállású vaskés töredéke. A nyéltüske rövid, vaskos. H.: 4,7 cm; sz.: $1,1 \mathrm{~cm}$.

13. Vastárgy (6. kép 14). Töredékes vastárgy. Restaurálás közben a vascsiholóhoz lett hozzáragasztva, egyértelmúen ennek a részét képezte, valószínúleg a sírrablás során tört le. H.: $2 \mathrm{~cm}$; sz.: $1,3 \mathrm{~cm}$.

14. Bronztárgy (6. kép 7-8).

14.1. Rögzítőszegecs, lapos „U” alakú. H.: 1,6 cm. Hossza megegyezik a tegezrögzítők hosszával.

14.2. Pálcatag, lapos „L” alakú. H.: $2 \mathrm{~cm}$. Az egyik szíjvég oldalmerevítőjének a töredéke.

3. kép. Bonyhád-Szöcske-szántók. A leletmentés során kibontott sír rajza és a leletek helyzete. (Rajz: Vicze László)

Fig. 3. Bonyhád-Szöcske-szántók. Drawing of the tomb unearthed during the rescue and the position of the finds. (Drawing: László Vicze) 
15. Bronz nagyszíjvég (6. kép 4). Lemezes, oldalpálcás, bronz nagyszíjvég. $H .: 8,7 \mathrm{~cm}$; sz.: 2,2 cm.

16. Bronz érme (6. kép 10). Római kori, teljesen lekopott bronzérme. Átm.: 2,2 cm.

17.1. Gyöngy (6. kép 11). A csontváz felszedését követôen a sír középső részén egy lapított gömb alakú gyöngy került eló. Átm.: 1,2 cm; v.: 0,7 cm; furat átm.: 0,3 cm.

17.2. Tegezveret (6. kép 26). Bronzlemezből préselt, gömbsordíszes, közepén félgömbbel díszített tegezveret, „U” alakú rögzítőszegeccsel. Átm.: $2 \mathrm{~cm}$. A tegezveretek sorába illik. A sírrablásnál vagy állatjárás során kerülhetett el az eredeti helyéröl.

\section{A leletanyag értékelése}

\section{Ezüsttálka}

A vékony lemezből készült bonyhádi ezüstedény gömbszelet formája a késő római largitiocsészék alakját őrzi, a tálka lelőkörülményei azonban későbbi készítésre és földbe kerülésre utalnak. A perem alatt domborított díszítésként tojássor és alatta négyszögletes, rombusz alakú minta fut körbe, amelyeket valamilyen megmunkáló padon verhettek rá. A vékony ezüstlemezt fára vagy bőrre is erősíthették, s a domborított minta a lemez rögzítését, a felső rész merevítését segíthette elő. Az ezüstedény kialakításának és megmunkálásának alacsony színvonala alapján provinciális mester terméke volt. A tálka hajlékonysága miatt csak abban az esetben volt alkalmas ivásra, étkezésre, ha bőrre vagy fára erősítették.

A félgömb alakú, ezüstből készült edények az I. századtól ismertek voltak a Római Birodalom és a Barbaricum területén. Ez az egyszerú forma, hosszú ideig élő típus, a 6-7. századi európai leletegyüttesekben is előfordul. Gyakran a párban talált ivócsészék az előkelők körében az italozási szokások vagy a közösségi rítus tanúi voltak. A bonyhádi tálhoz a Kárpát-medencei fémedények közül leginkább az 5. századi aquincumi kincslelet ezüstcsészéi hasonlíthatók, amelyek még őrzik a largitios csészék félgömbös formáját. ${ }^{3}$ Feltehetôen a bonyhádi tálka is egy $4-5$. századi hasonló alakú fém- vagy üvegedény utánzata lehetett. Hasonló formák megtalálhatók a 7. századi kuczurmarei (ma Velikij Kučurov, Ukrajna) leletben is. ${ }^{4}$ A Kárpát-medencei 6-10. századi különböző eredetú fémedényeket a nagyszentmiklósi kincsról írott monográfiájában Bálint Csanád gyújtötte össze. Az avar kori edények közül $22 \mathrm{db}$ ezüstpéldány ismert, de ezek

3 VIDA 2016, 53-54; 58-59.

4 Noll 1974, Abb. 56. közül egyik sem hasonlít a bonyhádi tálhoz. ${ }^{5}$ A bonyhádi tálat nem teljes félgömbszelet formája összeköti a 7. századra keltezhető nemesvarbóki (Zemianský Vrbovok, Szlovákia) ${ }^{6}$, zalesiei (Ukrajna) ${ }^{7}$ és kuczurmarei kincsek ezüsttáljaival is.

\section{Nyilhegyek}

Az avar kori nyílcsúcsokkal részletesen először Kalmár János foglalkozott, ${ }^{8}$ aki megállapította, hogy a csapott végü, illetve tompaszögú nyílhegyek kör alakú nyílásokkal nem fütyülő nyilak voltak, hanem túzgyújtók, amellett hogy kisebb vadak elejtésére is alkalmasak lehettek. ${ }^{9}$ Másik, máig érvényben lévő megállapítása volt, hogy a köpús nyílhegytípusok (miniatûr lándzsaforma) Meroving, germán örökségként terjedhettek el az avarok között. ${ }^{10}$ László Gyula korábbi feltételezését, amely szerint a sírokban talált nyilak számának rangjelző szerepe lehetett, ma már nem vallja a kutatás. ${ }^{11}$ A legutóbbi időkben Hergott Kristóf osztályozta a Tisza-Maros-Körös vidéken elókerült avar kori nyílcsúcsokat, ${ }^{12}$ Michal Holeščák pedig a szlovákiai nyílcsúcsokat rendszerezte. ${ }^{13}$ Hergott Kristóf két főcsoportot különített el, az első főcsoportnak tekintette a nyéltüskés nyílhegyeket, a második főcsoportba a köpús végú darabokat sorolta. Rendszerében az 1. és 2. csoport altípusai a háromélú (1.1/1.2) és kétélú (1.2./2.2) nyílcsúcsok. ${ }^{14}$

A háromélú, levél alakú, nyéltüskés, íves pengéjú/vágóélú nyílcsúcs Kalmár János gyújtésében a levél alakú, alsó harmadában szélesedő nyílcsúcsok közé sorolható. ${ }^{15}$ Hergott Kristóf csoportosítása alapján az 1 . számú bonyhádi nyílhegy leginkább a nyéltüskés főcsoport 1 . alcsoportjába tartozik, ezen belül is a levél alakúak (1.1.2) közé sorolható. ${ }^{16} \mathrm{Ez}$ a csoportosítás a pontatlan meghatározások és a pontos tipológia miatt bizonytalan. Michal Holeščák a főcsoportokat a nyílhegyek keresztmetszete alapján

\footnotetext{
5 BÁlint 2004, 305-315; VIDA 2017, 169-184.

6 SvobOda 1953, 33-108.

UGRIN 1987, 11-15, Fig. 1-5.

KALMÁR 1945, 283-294.

9 KALMÁr 1945, 284. Cs. Sebestyén Károly szerint ezekkel az átfúrt nyílhegyekkel leveleket küldtek. Cs. SEBESTYÉN 1932, 201.

10 KALMÁr 1945, 291.

11 LÁSZLÓ 1955, 150. A nyílcsúcsok rangjelző szerepének cáfolatára lásd RÉvÉSZ 1991, 621; CŚ́KY 2006, 115.

12 Hergott 2018, 138-154; Hergott 2019, 31-43.

13 HOLEŠČÁK 2015, 299-307.

14 HERGOTT 2018, 144-145.

15 KALMÁR 1945, 288. Fehértó A 63. sz. sír; 287. 2. kép. 10. ábra.

16 Hergott 2019, 33; 42, 5. kép; 2. ábra.
} 


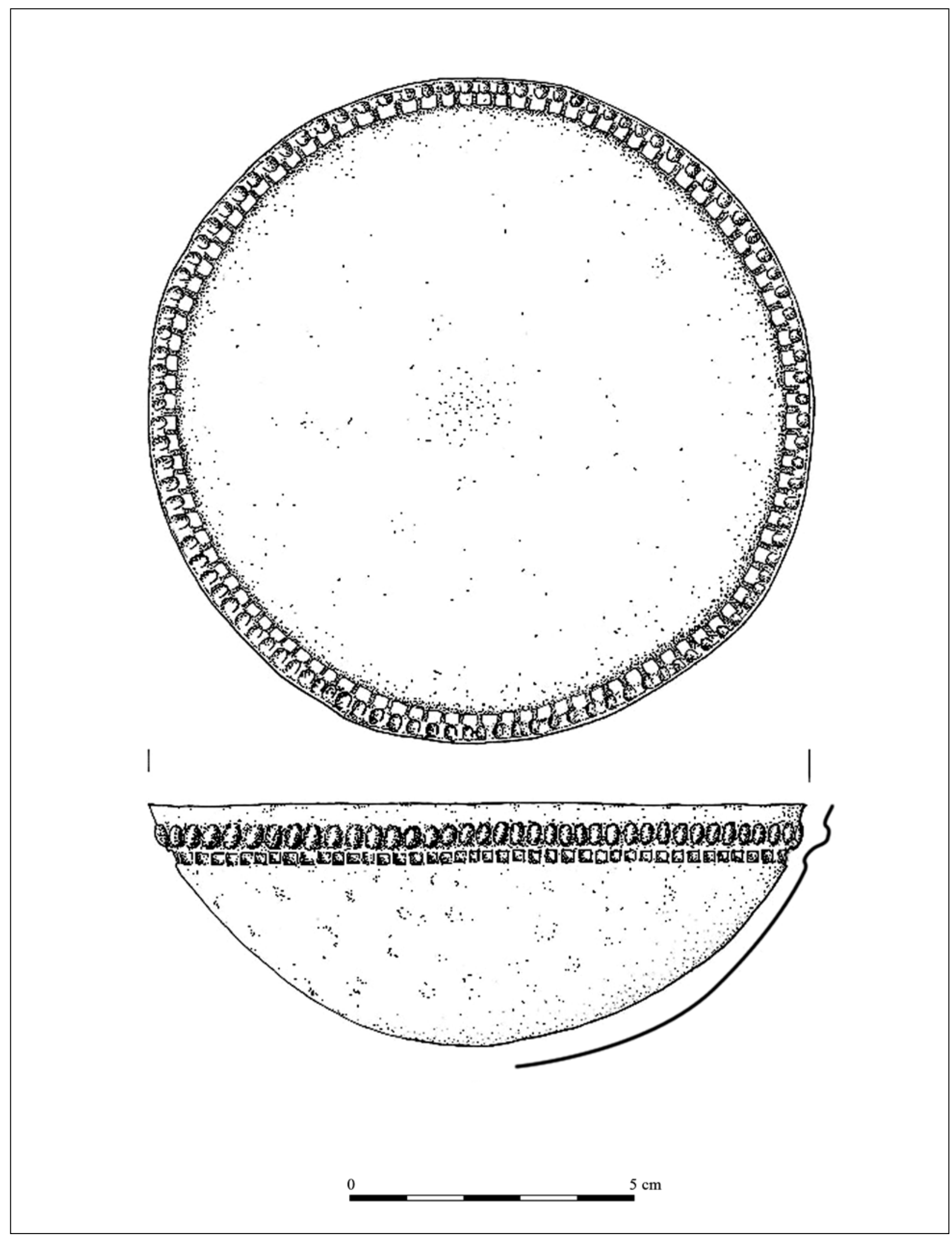

4. kép. Bonyhád-Szöcske-szántók. Az ezüst tálka rajza. (Rajz: K. Tóth Gábor)

Fig. 4. Bonyhád-Szöcske-szántók. Drawing of the silver bowl. (Drawing: Gábor K. Tóth) 


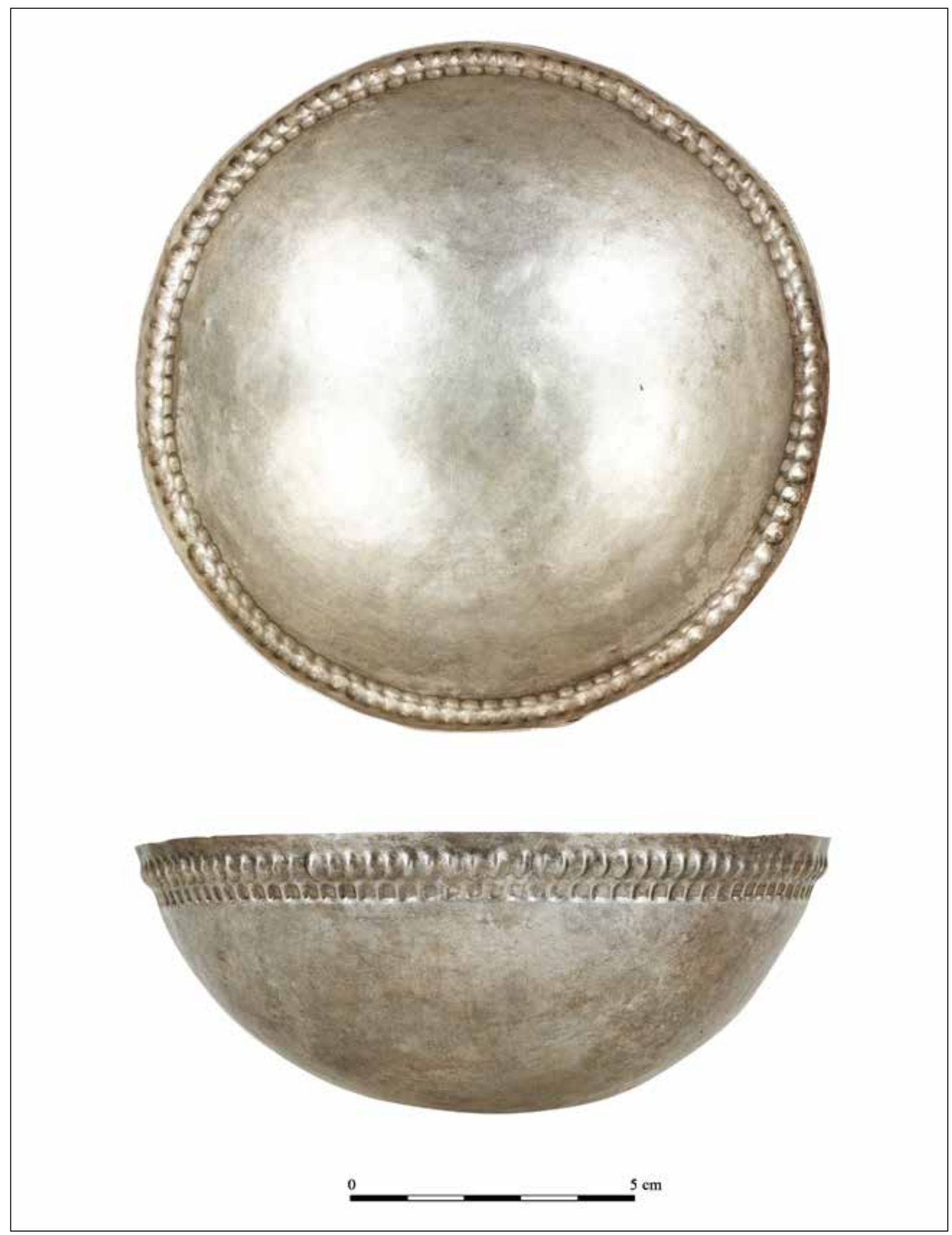

5. kép. Bonyhád-Szöcske-szántók. Az ezüst tálka fényképe. (Fotó: Cunder Tamás)

Fig. 5. Bonyhád-Szöcske-szántók. Photograph of the silver bowl. (Photo: Tamás Cunder) 


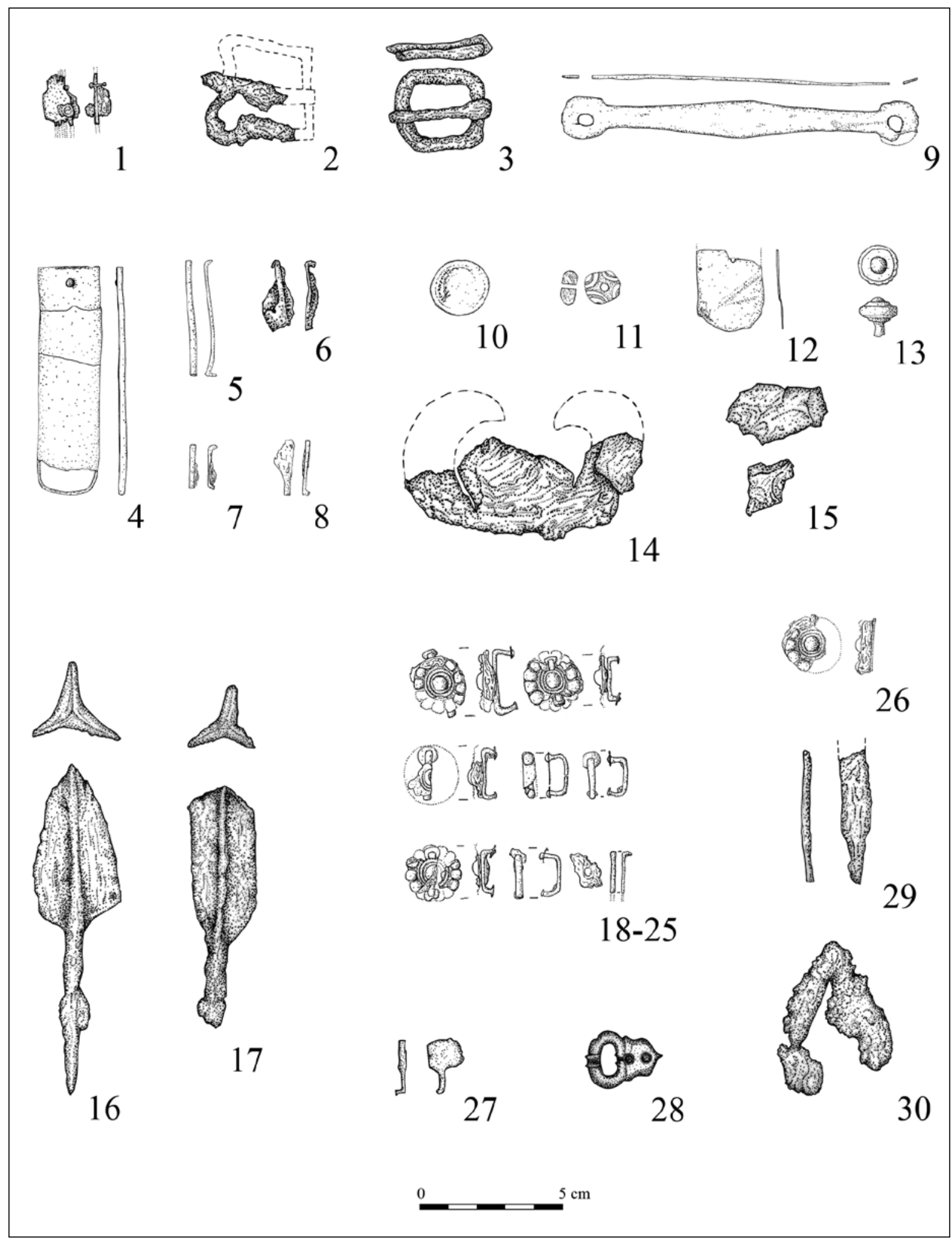

6. kép. Bonyhád-Szöcske-szántók. Leletek a sírból: 1: Két oldalas fésú töredéke; 2-3: Vas csatok; 4: Lemezes bronz nagy szíjvég; 5-8: Bronz övdísz lemezek merevítői; 9: Táska bronzzárja; 10: Római bronzérem; 11: Üveggyöngy; 12: Bronz kis szíjvég lemeze; 13: Bronz tú vége; 14: Vas túzcsiholó; 15: Túzkövek; 16: Vas háromszárnyú nyílcsúcsok; 18-26: A tegez bronzrozettás veretei; 27: Övveret bronztöredéke; 28: Kis bronzcsat; 29: Vaskés töredéke; 30: Vastöredék (Rajz: Csiszér Antal)

Fig. 6. Bonyhád-Szöcske-szántók. Finds from the tomb: 1: Fragment of a two-sided comb; 2-3: Iron buckles; 4: Plate of the large bronze belt end; 5-8: Bronze belt plate stiffeners; 9: Bronze Closures of a bag; 10: Roman Bronze Coin; 11: Glass Beads; 12: Plate of the small bronze belt end; 13: Bronze pine end; 14: Iron Fire Chisel; 15: Flintstones; 16: Iron Three-Wing Arrowheads; 18-26: Bronze rosette fittings of quiver; 27: Bronze fragment of belt; 28: Small bronze buckle; 29: Fragment of iron knife; 30: Fragment of iron (Drawing: Antal Csiszér) 
határozta meg: A lapos; $\mathrm{B}$ háromélü; $\mathrm{C}$ négyzetes keresztmetszetú; D kerek keresztmetszetú. Az alcsoportokat formai jegyek alapján kilenc csoportra osztotta. Ezen belüli alcsoportok legfontosabb eleme a köpús vagy nyéltüskés kialakítás (0 és 1 kódok). Holeščák tipológiája sokkal jobban kidolgozott és jobban megfelel nyílcsúcsaink osztályozásához. Ez alapján a bonyhádi 1. számú nyílhegy a B fócsoport könnycsepp alakú alcsoportjába (II.), Michal Holeščák kódrendszere szerint BII1 típusba sorolható. Az avar nyílhegyek pontos időrend meghatározására nem alkalmasak.

A Kalmár János munkájában szereplő háromélú, nyéltüskés, tompaszögú nyílhegy $(4.2)^{17}$ pontos párhuzama hiányzik Hergott Kristóf és Michal Holeščák csoportosításából. A tompaszögú deltoid alakú nyílhegyek Hergott munkájában az 1.2.2 csoportot alkotják, a hatszögletúek pedig az 1.1.4 csoportot, ${ }^{18}$ e két csoport közös metszetébe tartozik a 2 . számú nyílhegyünk. Holeščák adatbázisában, leginkább az AIVa1 csoportban találunk hasonló darabokat, ezek háromélúek, deltoid alakúak és nyéltüskések, a legnagyobb szélességük a felső harmadban található. ${ }^{9} \mathrm{~A}$ hatszögletú darabok a szlovákiai anyagból hiányoznak. Tisza-Maros-Körös vidékén Szentes-Berekhát, Buzi Farkas Imre földjének 30. sírjából került elő hatszögletú nyílhegy. A temetőt a 7. század utolsó harmadára, illetve a 8. század első harmadára datálták, ${ }^{20}$ de a sír É-D-i tájolása elsősorban a kora avar kor I. fázisában volt szokásban. ${ }^{21}$

A lapos, kétélú, levél alakú nyílhegy (4.3) töredékes, a Kalmár János féle lapos, kétélú, köpüs kialakítású nyílhegyek közé sorolható. ${ }^{22}$ Hergottnál a nyéltüskés/köpüs, kétélú, levél alakú csoportba tartozik $(1 / 2.2 .3),{ }^{23}$ és Holeščák AII-es típusa közé tartozna, de ez a csoport szintén hiányzik Szlovákia területéről. ${ }^{24}$ Tisza-MarosKörös vidékén Szentes, Lapistó 20. sír, ${ }^{25}$ és Pitvaros, 51. sír ${ }^{26}$ anyagában voltak hasonló példányok. Mindkettő a késő avar korra datált. A homokrévi/mokrini 67. sír, ${ }^{27}$ melyben kétélú

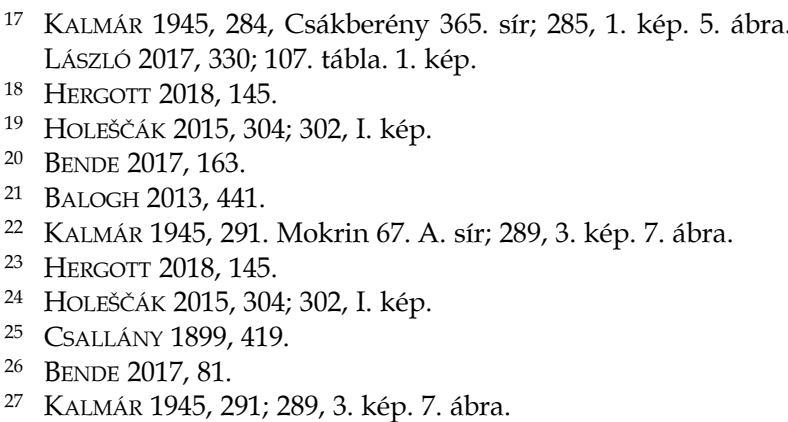

levél alakú nyílhegy is volt, a 7. század elejére, első évtizedeire keltezhető. ${ }^{28}$ Az ilyen típusú nyílcsúcsok az avar időszakban egészében jelen voltak.

A három nyílcsúcs funkciója alapján háromféle tevékenységre utal. A 4.1. számú háromélú, levél alakú nyílcsúcs harcászati célú, a 4.2. számú háromélú, tompaszögú nyílhegy kisvadra történő vadászatra, a 4.3. számú lapos, kétélú, levél alakú nyílhegy pedig nagyvadra történő vadászatra volt alkalmas.

\section{Tegez veretei és záró csatja}

A kilenc darab bronzlemezból préselt, gömbsordíszes, közepén félgömbbel díszített, tegezveretet ólomba ágyazott, „U" alakú szegecsekkel rögzítettek. Ez a típus a környei avar temető rozettás tegezvereteinek a " $b$ " csoportjába tartozik. A vereteknél a középső félgömb alakú részt, két borda veszi körül. ${ }^{29}$ A környei temetô a 6 . század végére a 7. század első felére keltezett. ${ }^{30}$

Az egytagú, címer/pajzs alakú tegezzáró csat legjobb hazai párhuzamai kora avar temetókból kerültek elő: Csákberény-Orondpuszta 219. sír; ${ }^{31}$ Keszthely-Fenékpuszta 15. sír;32 Környe 60. sír ${ }^{33}$ és Szeged-Fehértó A 34. sír. ${ }^{34}$ Ez a típus a kora és közép avar kori övkészletek jellemző darabja. ${ }^{35} \mathrm{~A}$ környei 60 . számú sírnak a tegezveretei is ugyanolyan típusúak, mint a bonyhádiak. ${ }^{36}$

\section{Tarsolyzáró}

A sárgarézből öntött tarsolyzáró végei körívesek és átlyukasztottak. A tarsolyzárók legutóbbi feldolgozója, Tobias Bendeguz hét csoportba sorolta ezeket a tárgyakat, melyeken belül további altípusokat határozott meg. A bonyhádi darab az 1. típusba tartozik, azon belül is az $1 a 1$ alcsoportba. Ennek a csoportnak a formai jegyei a hosszúkásan elnyújtott, középen kiszélesedő, piskóta alakú lemez egy-egy lyukkal a végén. Ez a csoport kronológiailag a kora avar korra tehetó. ${ }^{37}$ Érdekessége ezeknek a tárgytípusoknak,

28 BALOGH 2016, 197.

29 SALAMON-ERdÉlyI 1971, 52-54. Környe: 23, 60, 75 sír; 119, II. tábla, 1-8. ábra. Mór 25. sír és Linz-Zizlau 74. sír. SALAMONERDÉLYI 1971, 54, 184-186. lábjegyzet.

30 SALAMON-ERDÉLYI 1971, 71.

31 LÁSZLÓ 2017, 160; 158, 40. ábra, 2.6.1. ábra.

32 GARAM 2001, 91; 307, 56. tábla, 1. ábra.

33 SALAMON-ERDÉLYI 1971, 52; 85, 33. ábra.

34 GARAM 2001, 92; 308, 57. tábla, 1. ábra.

35 GARAM 2001, 94; LÁSZLÓ 2017, 160.

36 A környei temetőt Török Gyula a 6-7. század fordulójára keltezte. TÖRÖK 1954, 59.

37 TOBIAs 2011, 279. 
hogy funkciójukat tekintve másodlagos felhasználásúak, eredetileg templomi füstölóknek a függesztőelemei lehettek. ${ }^{38}$ Háromágú bizánci füstölő függesztőtagok avar kori temetőkből Ada-Komlós-téglagyár/Ada-Ciglana Komloš ${ }^{39}$ és Szekszárd-Tószegi dúlői 389. sírból adatolhatók. ${ }^{40}$ Egyértelmú ábrázolás található Dalton korai keresztény tárgyakat összegyújtő katalógusában. ${ }^{41}$

\section{Övgarnitúra}

A lemezes szíjvégek a kora és közép avar kor jellegzetes elemei. A lekerekített aljú, párhuzamos, egyenes oldalú változat inkább a kora avar korra keltezhető. ${ }^{42}$ A lekerekített végú, két lemezből egy pálcataggal összeállított bronz nagyszíjvég (6. kép 4) a 7. századtól elterjedt a Kárpát-medencében, és közép avar korban is előfordul. ${ }^{43} \mathrm{Az}$ itt taglalt kisszíjvég nem a tarsoly tartalmát képezte, hanem a tarsoly alatt volt, és hozzátapadt a vascsiholóhoz.

\section{Vascsiholó}

Az enyhén ívelt hátú csiholó vas két vége elkeskenyedik és visszahajlik, a háta belső íve enyhén csúcsos. A csiholónak a Szolnok-Szanda-i gepida temetó 135. sírjában található az egyik legközelebbi párhuzama. ${ }^{44} \mathrm{Az}$ avar kori csiholók közül a Tiszafüred 1149. és 113. sírból kerültek elő hasonló példányok. Ezek is kissé ívelt hátúak, a végeik azonban hosszabban és erőteljesebben hajlanak vissza. ${ }^{45}$ A töredékes csiholóvas pontosabb for- mai meghatározása végeinek hiányossága miatt nehézségekbe ütközik.

\section{Gyöngy}

A lapított gömb alakú gyöngy a csontváz felszedését követően a sír középső részén került elő. A gyöngy színe vöröses alapon törtfehér. A gyöngy dudoros, négyszeres hurokfolyatott rátétdíszes. A hasonló példányok többek között a Csákberény-Orondpusztán feltárt 240. és 356. sírból, ${ }^{46}$ a Szekszárd-Bogyiszlói úti temető 238., 680. és 730. sírjából ${ }^{47}$ és a Székkutas-Kápolnadúlő sírmező 18. sírjából ${ }^{48}$ kerültek elő. Ezeknek a gyöngyöknek a divatja a 6. század harmadik harmadától a 7. század első-második harmadáig tartott. Talán a tarsolyt díszítette vagy bajelhárítóként a tartalmát képezte. ${ }^{49}$

\section{Összegzés}

A sír leletei között a gyöngy és a tegezveretek a 6. század végére, a 7. század elejére, a tarsolyzáró és a párhuzamos lemezes, oldalpálcás szijvégek tágabban a kora avar korra datálják a sírt. A leletegyüttesben a tarsolyzárként szolgáló egykori bizánci füstölőhöz tartozó elem és az ezüst csésze a bizánci Balkán térségében egy kirabolt templom felszereléséből származhat, és egy olyan személy leletegyütteséhez tartozhatott, aki maga is részt vett az avarok balkáni hadjárataiban, vagy ilyen személyekkel kapcsolatban volt.

\title{
IRODALOM
}

\author{
BALOGH CSILla \\ 2013 A Duna-Tisza köze avar kori betelepülésének problémái (The colonization problems at between the \\ Danube and Tisza in the Avar Age). Budapest. \\ 2016 Régészeti adatok a Duna-Tisza közi avarok történetéhez (The History of the Avars in the Danube-Tisza \\ Interfluve as Reflected in the Archaeological Record). Studia ad Archaeologiam Pazmaniensiae Vol. 6. \\ Budapest. \\ BÁLINT CSANÁD \\ 2004 A nagyszentmiklósi kincs. Régészeti tanulmányok. Varia Archaeologica Hungarica 16. Budapest.
}

\footnotetext{
38 LAKATOS 2001, 149; Füstölők mellett a templomi mécsestartóknak is lehetett két végén lyukas függesztőeleme. Byzanz. Das Licht aus dem osten. Kult und Alltag im Byzantinischen Reich vom 4. bis. 15. Jahrhundert. Ausstellungskatalog. Padernborn 2001, 145-146, Kat. I.48; 211212, Kat. II.7.

39 LÖRINCZY-STRAUB 2003, 174; 182.

40 ToBias 2011, 279.

41 Dalton 1901, 85, a-b ábra.
}

42 SOMOGYI 1984, 85.

43 KISS 1984, 140; LÁSZLÓ 2017, 161.

44 Garam 2011, 163; 176. 2. ábra, 8. kép.

45 GARAM 2011, 164; GARAM 2011, 178. 4. ábra

46 LÁSZLÓ 2017, 125; 131, 29. ábra. 11.2 és 11.6 ábra.

47 PÁsZTOR 2001, 122.

48 PÁsztor 2003, 335; 351; 367, 3. kép. 10. 1. ábra.

49 PÁszTor 1996, 48. 
BENDE LÍVIA

2017 Temetkezési szokások a Körös-Tisza-Maros közén az avar kor második felében. Bestattungsbräuche in der zweiten Hälfte der Awarenzeit im Gebiet zwischen Körös, Theiss und Maros. Studia ad

CSALLÁNY GÁBOR Archaeologiam Pazmaniensiae 8. Piliscsaba-Budapest.

1899 Népvándorláskori temetőről Szentesen. Archaeologiai Értesítő (Budapest) 19, 416-419.

CSÍKY GERGELY

2006 A zsebesi avar temető fegyveres rétege. Tatabányai Múzeum Tudományos Füzetek (Tatabánya) 8, 111-124.

DALTON, ORMONDE MADDOCK

1901 Catalogue of early Christian antiquities and objects from the Christian East in the Department of British and mediaeval antiquities and ethnography of the British museum. London.

GARAM ÉVA

2001 Funde byzantinischer Herkunft in der Awarenzeit vom Ende des 6. bis zum Ende des 7. Jahrhunderts. Monumenta Avarorum Archaeologica. 5. Budapest.

2011 „...A tǔz csiholója” In: T. Biró K.-Markó A. (szerk.): Emlékkönyv Violának. Tanulmányok T. Dobosi Viola tiszteletére. Budapest.

\section{HERGOTT KRISTÓF}

2018 Avar kori nyílhegyek a Körös-Tisza-Maros vidéken (Avar age arowheads from Körös-Tisza-Maros region). In: Kovács A.-Bíró Gy. (szerk.): Móra Akadémia Szakkollégiumi Tanulmánykötet. Szakkollégiumi Füzetek 5. Szeged, 138-154.

2019 Avar kori nyílhegyek a Tisza-Maros-Körös vidéken. A temetkezési szokások. Veritatis Imago (Szeged) 2019/2-3, 31-43.

HOLEŠČÁK, MiCHAL

2015 Early medieval arrowheads from the area of todays Slovakia. In: Cosma, C. (ed.): Warriors, weapons, KALMÁR JÁNOS and harness from the 5th-10th centuries in the Carpathian Basin. Cluj-Napoca.

1945 Az avar nyílhegy. Die Typen der awarischen Pfeilspitzen. Archaeologiai Értesítő (Budapest) 5-6, 283-294.

Kiss ATtila

1984 A regölyi temető. Das Gräberfeld von Regöly. In: Kiss G.-Somogyi P. (eds): Tolna megyei avar temetők (Awarische Gräberfelder im Komitat Tolna). Dissertationes Pannonicae Ser. 3, Vol. 2. Budapest. 123-150.

LAKATOS Attila

2001 Închizãtoare de geantã din bronz în mediul avar (sec. VI-VII p. Chr.). Bronzene Taschenverschlüsse im awarischen Milieu (6.-7. Jh. n. Chr.). Ephemeris Napocensis (Cluj-Napoca) 11, 145-163.

LÁSZLó GYULA

1955 Études archéologiques sur l'histoire de la société des Avars. Archaeologia Hungarica 34. Budapest.

2017 A csákberény-orondpusztai avar kori temető. In: Szentpéteri J. (szerk.): A Szent István Király Múzeum Közleményei A sorozat 53. Székesfehérvár.

LÓRINCZY GÁbOR-STRAUb PÉTER

2003 Újabb adatok az avar kori szúrőkanalak értékeléséhez I. (Neue Angaben zur Bewertung der awarenzeitlichen Sieblöffel I.) A Móra Ferenc Múzeum Évkönyve - Studia Archaeologica (Szeged) 9, 171-187.

NOLL, RUDOLF

1974 Vom Altertum zum Mittelalter. Katalog der Antikensammlung I. Kunsthistorisches Museum, Wien.

PÁSZTOR ADRIEN

1996 A csákberény-orondpusztai avar kori temető gyöngyleleteinek tipokronológiai vizsgálata (The Typochronological Examination of the Bead Finds of the Csákberény-Orondpuszta Cemetery from the Avar Period). Savaria - Pars Archaeologica (Szombathely) 22/3, 37-83.

2001 A Szekszárd-Bogyiszló úti avar kori temető gyöngyleletei (Die Perlenfunde des Gräberfeldes an der Strasse Szekszárd Bogyiszló). A Wosinsky Mór Múzeum Évkönyve (Szekszárd) 23, 115-160.

2003 A székkutas-kápolnadúlői avar temető gyöngyleletei. Die Perlen des awarenzeitlichen Gräberfeldes von Székkutas-Kápolnadúlő. In: B. Nagy K.: A székkutas-kápolnadúlői avar temető. A Móra Ferenc Múzeum Évkönyve - Monographia Archeologica 1. Szeged, 331-370.

RÉVÉSZ LÁSZLÓ

1991 Voltak-e nagycsaládi temetői a honfoglaló magyaroknak? A Móra Ferenc Múzeum Évkönyve (Szeged) 1984-85, 615-639.

SALAMON ÁGNES-ERDÉLYI ISTVÁN

1971 Das völkerwanderungszeitliche Gräberfeld von Környe. Studia Archaeologica 5. Budapest.

Cs. SEBESTYÉn KÁROLY

1932 "A sagittis Hungarorum...” A magyarok íjja és nyila. Dolgozatok a m. kir. Ferenc József Tudományegyetem Archaeologiai Intézetéből (Szeged), 167-226. 


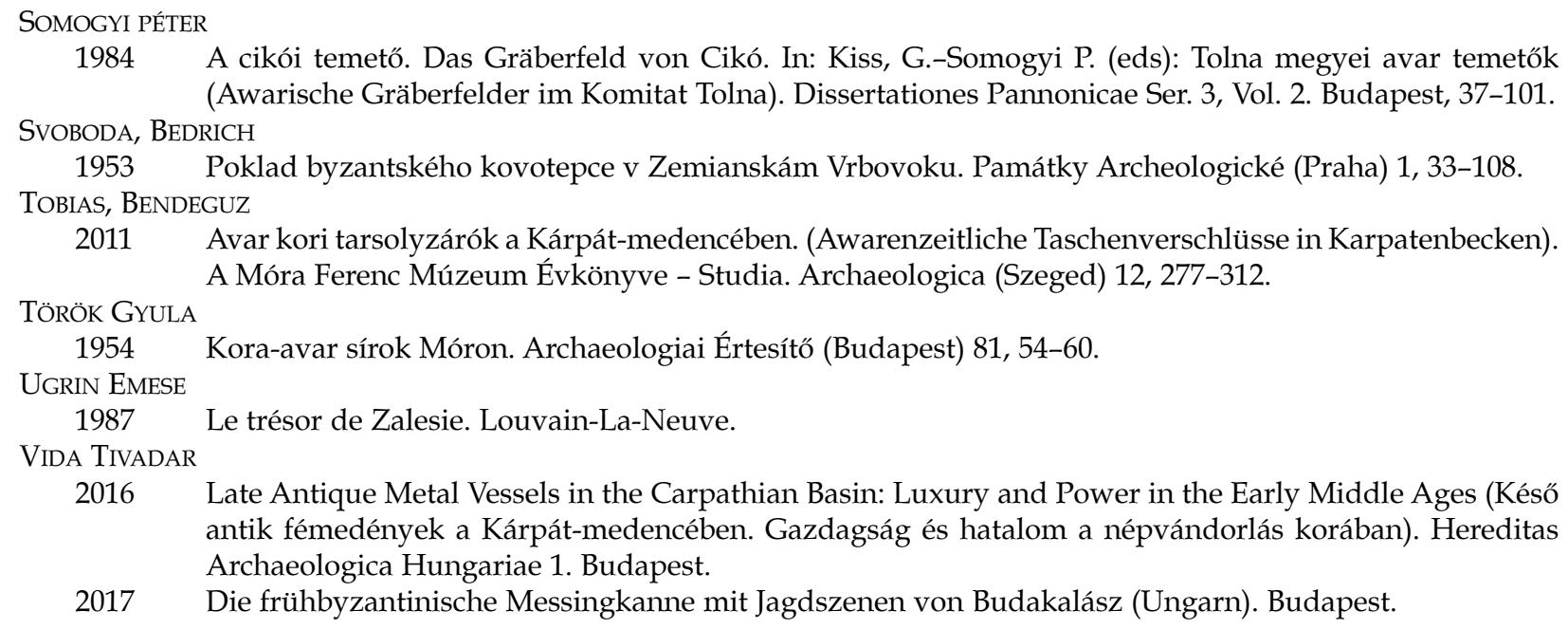

\section{A SILVER BOWL FROM AN EARLY AVAR BURIAL FOUND AT BONYHÁD (COUNTY TOLNA, HUNGARY)}

\section{GÁBOR K. TÓTH}

In spring 2018, the archaeologists of the Wosinszky Mór County Museum (Attila Czövek and Gábor K. Tóth) inspected the area known as Szöcske-szántók lying north of Bonyhád after being notified of finds by museum friend metal detectorist (László Bulla and Péter Vincze). The area lies on a west to east running prominent elevation (110-130 m a.s.l.) at the confluence of the Majosi-árok and Aparhant Streams. The site was occupied during several periods from the Roman Age to the Modern Age. A relatively richly furnished burial was found in one of the boundary ditches. The most remarkable find was a semi-spherical silver bowl with repoussé ornamentation under its rim; the other finds from the burial were the fragment of a bone comb, three arrowheads, eight quiver mounts, a quiver buckle, a large and a small strap-end, a bronze purse clasp (originally the suspension element of a Byzantine censer or oil-lamp), an iron strike-a-light and two flints, an iron knife, two iron buckles and a Roman coin. The bead and the quiver mounts can be dated to the late 6th-early 7th century, the purse clasp and the strapends made up of two plates and a side-strip to the broader Early Avar period. The purse clasp had originally been part of a Byzantine censer, which, together with the silver bowl, obviously originated from a looted church in Byzantium's Balkanic province and were the possessions of a person who had participated in the Avars' Balkanic campaigns or who had contact with these individuals.

A cikk a Creative Commons Attribution 4.0 International License (https://creativecommons.org/licenses/by/4.0) feltételei szerint publikált Open Access közlemény, melynek szellemében a cikk bármilyen médiumban szabadon felhasználható, megosztható és újraközölhető, feltéve, hogy az eredeti szerző és a közlés helye, illetve a CC License linkje és az esetlegesen végrehajtott módosítások feltüntetésre kerülnek. (SID_1) 